\title{
Evaluation of a polymerase chain reaction-based assay for the detection of Aeromonas salmonicida ss salmonicida in Atlantic salmon Salmo salar
}

\author{
S. Høie*, M. Heum, O. F. Thoresen \\ Central Veterinary Laboratory, PO Box 8156 Dep., N-0033 Oslo, Norway
}

\begin{abstract}
A PCR-based assay was developed to detect Aeromonas salmonicida ss salmonicida (A.s.s.) in infected fish kidney and gills. Samples processed for PCR (polymerase chain reaction) were $100 \mathrm{ml}$ kidney tissue suspensions and gill swabs. The primers and probes employed were derived from sequences of $16 \mathrm{~S}$ rRNA as well as from plasmid DNA. In order to estimate in vitro sensitivity, various numbers of colony forming units (CFU) of A.s.s. strains were added to kidney and gill samples. A minimum of 20 and $200 \mathrm{CFU}$ were demonstrated in $10 \mu \mathrm{l}$ PCR template by the $16 \mathrm{~S}$ rDNA and the plasmid primers, respectively. The 20 and $200 \mathrm{CFU}$ per $10 \mu \mathrm{l} \mathrm{PCR}$ template correspond to $10^{3}$ and $10^{4} \mathrm{CFU}$ in $100 \mathrm{ml}$ kidney tissue suspension. The in vitro specificity testing showed that DNA from A.s.s., A. hydrophila, A. salmonicida ss achromogenes, A. salmonicida ss masoucida, and atypical $A$. salmonicida were amplified using the $16 \mathrm{~S}$ rDNA primers. Only A.s.s. and A. salmonicida ss achromogenes DNA were amplified using the plasmid primers. Altogether 25 Atlantic salmon parr, experimentally challenged by cohabitation, were tested for the presence of $A$.s.s. by PCR and agar cultivation. The rates of recovery were $13 / 25$ by $\mathrm{PCR}$ and $6 / 25$ by agar cultivation. Kidney and gill samples from Atlantic salmon of about $2 \mathrm{~kg}$, obtained at slaughter and considered covertly infected with A.S.S., were also tested. A.s.s. was detected neither by PCR nor by cultivation. Additionally, kidney samples from feral brood fish were tested. A.s.s. was more frequently, 24/72, detected by PCR than with agar cultivation, 6/72.
\end{abstract}

KEY WORDS: Aeromonas salmonicida ss salmonicida PCR - Agar cultivation - Kidney - Gill swabs Experimentally infected fish · Feral brood fish · Covertly infected fish · Atlantic salmon

\section{INTRODUCTION}

Aeromonas salmonicida is the causative agent of furunculosis in salmonids and related diseases in other fish species (Inglis et al. 1993). The terms typical and atypical $A$. salmonicida were introduced to distinguish between strains causing furunculosis in salmonids, and related strains isolated from other disease conditions in salmon and other fish species (Austin \& Austin 1993, Inglis et al. 1993). DNA:DNA reassociation analysis and numerical taxonomic studies have revealed that the typical group is a homogenous taxon, while the atypical $A$. salmonicida strains are more diverse (Belland \& Trust 1988, Austin et al. 1989). Multilocus

•E-mail: steinar.hoie@vetinst.no enzyme electrophoresis have shown that the population structure of A. salmonicida is clonal, corresponding to only 2 clones for the species (Boyd et al. 1994). Classification of the bacterium into various subspecies has been proposed with the subspecies salmonicida comprising the typical A. salmonicida (McCarthy \& Roberts 1980, Popoff 1984).

Aeromonas salmonicida ss salmonicida (A.s.s.), typical $A$. salmonicida, may be readily recovered from the kidney of diseased fish on standard non-selective bacteriological agar media (Austin \& Austin 1993). However, the bacterium is difficult to detect in covertly infected fish, such as covert carrier fish, by culture isolation methods, as these methods are too insensitive (McCarthy \& Roberts 1980). An alternative approach to the identification of covertly infected fish has been to activate infections with a combination of cortico- 
steroid injection and heat stress (Bullock \& Stuckey 1975). ELISA techniques for the detection of $A$. salmonicida have also been developed, and the bacterium has been demonstrated in live, apparently healthy Atlantic salmon sampled during an outbreak of furunculosis in seawater (Adams \& Thompson 1990). However, both successful and unsuccessful identification of covertly infected fish by examination of the kidney with ELISA have been reported (Rose et al. 1990, Hiney et al. 1994).

To overcome the problems of identifying covertly infected fish, highly sensitive methods are needed. There are reasons to believe that the polymerase chain reaction (PCR) could improve method sensitivity (Saiki et al. 1988), and PCR has been employed for the detection of Aeromonas salmonicida in fish tissue and water (Gustafson et al. 1992, Hiney et al. 1992, O'Brian et al. 1994). So far, it has been difficult to find probes or primers derived from DNA sequences which distinguish between A.s.S. and atypical $A$. salmonicida (Gustafson et al. 1992, Hiney et al. 1992). Furthermore, no elaborate studies have been performed to evaluate the suitability of PCR for the detection of A.s.s. in field samples from fish.

The purposes of the present study were (1) to develop a PCR-based assay for the detection of A.s.s. in kidney tissue and gill swabs, (2) to determine the in vitro sensitivity/specificity of primers derived from sequences of $16 \mathrm{~S}$ rDNA as well as plasmid DNA of A.s.S., (3) to evaluate the suitability of the assay used on experimentally infected fish in freshwater and (4) to test field samples obtained from farmed Atlantic salmon at slaughter and feral brood fish at spawning.

\section{MATERIALS AND METHODS}

Agar cultivation from kidney samples and gill swabs. Mid kidney samples were transferred directly to sterile plastic tubes after sampling. A loopful of kidney tissue and one gill swab were streaked onto blood agar (BA) plates [heart infusion agar (Difco, Detroit, MI, USA) with $5 \%$ bovine blood], incubated for $5 \mathrm{~d}$ at $22^{\circ} \mathrm{C}$, and then examined for the presence of bacterial colonies with the characteristics of A.s.s. Bacterial colonies with the characteristics of A.s.s. were subcultured on BA plates for purity, and were morphologically and biochemically identified.

Preparation of kidney samples and gill swabs prior to PCR. The tissue samples and the gill swabs were stored at $-70^{\circ} \mathrm{C}$ until prepared for PCR. Approximately $0.5 \mathrm{~g}$ kidney tissue was placed in a plastic petri dish (diameter $3.5 \mathrm{~cm}$ ) (Nunc, Intermed, Denmark) with $3 \mathrm{ml}$ phosphate buffered saline (PBS) pH 7.2. A tissue suspension was achieved by pressing the tissue through a metal mesh. Two parallel aliquots, each containing $100 \mu \mathrm{l}$ tissue suspension, were transferred to microcentrifuge tubes. A total of $1 \mathrm{ml}$ PBS was added to the tissue suspensions, while the gill swabs were submerged in $1 \mathrm{ml}$ PBS in microcentrifuge tubes for $30 \mathrm{~min}$. The tubes were centrifuged at $12000 \times \mathrm{g}$ for $2 \mathrm{~min}$. The supernatants were discarded and the pellet was washed once in $1 \mathrm{ml}$ PBS

After washing, the kidney material was resuspended in $500 \mu \mathrm{l}$ PCR buffer [ $50 \mathrm{mM} \mathrm{KCl}, 10 \mathrm{mM}$ Tris-HCl pH $=8.0,2.5 \mathrm{mM} \mathrm{MgCl}_{2}, 0.1 \%(\mathrm{w} / \mathrm{v})$ gelatin, $0.45 \%(\mathrm{w} / \mathrm{v})$ Nonidet P40, 0.45\% (w/v) Tween 20] (Higuchi 1989) and $10 \mu \mathrm{l}$ of Proteinase K (Sigma Chemicals, St. Louis, $\mathrm{MO}$, USA) $\left[2.5 \%(\mathrm{w} / \mathrm{v})\right.$ in $\left.\mathrm{H}_{2} \mathrm{O}\right]$, while the gill material was resuspended in $100 \mu \mathrm{l}$ PCR buffer and $2 \mu \mathrm{l}$ Proteinase $\mathrm{K}$. The samples were placed in a heating block (Dri-Block, Techne Inc., Princeton, NJ, USA) at $56^{\circ} \mathrm{C}$ for $1 \mathrm{~h}$, and subsequently ultrasonicated in a waterbath (Transsonic, Elma, Germany) for $10 \mathrm{~min}$ at the same temperature. Another 4 and $2 \mu$ l of Proteinase $\mathrm{K}$ were added to the kidney and gill samples, respectively, followed by further incubation at $56^{\circ} \mathrm{C}$ for $1 \mathrm{~h}$. The temperature was increased to $95^{\circ} \mathrm{C}$ for $10 \mathrm{~min}$ and the samples were subsequently cooled on ice and centrifugated at $12000 \times g$ for $10 \mathrm{~s}$. Volumes of $10 \mu \mathrm{l}$ of the supernatants were used as the template for PCR amplification.

Primers and isotopically end-labeled probes. One primer set was derived from the sequence of $16 \mathrm{~S}$ rRNA of A.s.s. (Table 1) (Høie et al. 1996). The other primer set was based on sequences of a $5.0 \mathrm{~kb}$ (3.4 MDa) plasmid of A.s.s. (Sørum et al. 1993, H. Sørum pers. comm. 1996). For the confirmation of PCR products 1 internal oligonucleotide probe was selected for each primer set (Table 1). The primers and probes were synthesized at the University of Oslo, Norway. End-labeling was performed with 100 pmol of the probes with $\left[\gamma^{32} \mathrm{P}\right] \mathrm{ATP}$ (Amersham, UK) and T4 polynucleotide kinase (Boehringer Mannheim, Germany) (Sambrook et al. 1989). The probe was then extracted with phenol/ chloroform and purified on a Sephadex G-50 column.

PCR. Samples were subjected to PCR in a total volume of $50 \mu$ covered by mineral oil (Sigma Chemicals). Each sample $(10 \mu \mathrm{l})$ was added to $40 \mu \mathrm{l}$ of a mixture of PCR reagents, yielding a final concentration of $10 \mathrm{mM}$ Tris-HCl $\rho \mathrm{H} 8.3,50 \mathrm{mM} \mathrm{KCl}, 3.0 \mathrm{mM} \mathrm{MgCl}, 0.01 \%$ gelatin, $200 \mathrm{mM}$ of each of the deoxyribonucleosides, $1 \mathrm{mM}$ of each $16 \mathrm{~S}$ rDNA primer and $1 \mathrm{U}$ of thermostable DNA polymerase (Amplitaq, Perkin Elmer Cetus, CT, USA). For the plasmid primers the conditions were slightly different, as a final concentration of $2.0 \mathrm{mM} \mathrm{MgCl}_{2}$ and $0.25 \mathrm{mM}$ of each primer were used.

PCR amplification was performed in a thermocycler (Biometra Biomedizinische Analytik, Göttingen, Germany) by initial denaturation at $94^{\circ} \mathrm{C}$ for $2 \mathrm{~min}$, then 40 
Table 1. Primers and probes used in the PCR for the detection of A.s.s. The numbering system used for the $16 \mathrm{~S}$ rRNA derived primers is the Escherichia coli sequence numbering system

\begin{tabular}{|c|c|c|c|}
\hline & Position & Sequence $\left(5^{\prime}-3^{\prime}\right)$ & Product length (bp) \\
\hline \multicolumn{4}{|l|}{ 16S rDNA } \\
\hline Forward primer & $212-231$ & GGC CTT TCG CGA TTG GAT GA & \multirow{3}{*}{271} \\
\hline Reverse primer & $484-459$ & TCA CAG TTG ACA CGT ATT AGG CGC & \\
\hline Probe & $347-366$ & GGA GGC AGC AGT GGG GAA TA & \\
\hline \multicolumn{4}{|l|}{ Plasmid } \\
\hline Forward primer & & TCA AAC AGC GGC AAG AGC AGG & \multirow{3}{*}{ ca 710} \\
\hline Reverse primer & & GCT CGC TCC TTG TGC TCT TCT & \\
\hline Probe & & CGG GAC GGG ATA AAG GGA TT & \\
\hline
\end{tabular}

cycles of 1 min of denaturation at $94^{\circ} \mathrm{C}, 1$ min of primer annealing at $54^{\circ} \mathrm{C}$ and $65^{\circ} \mathrm{C}$ for the 16SrDNA primers and plasmid primers, respectively, and $1 \mathrm{~min} 30 \mathrm{~s}$ of extension at $72^{\circ} \mathrm{C}$.

Inhibition of the PCR was evaluated by dividing each sample into 2 aliquots, and $3 \mathrm{ng}$ A.s.s. DNA per $10 \mu \mathrm{l}$ sample was added to one of the aliquots, which was called the inhibition control. Samples were considered not to inhibit the thermostable polymerase when the inhibition controls exhibited a strong, visible band of expected size after gel electrophoresis and ethidiumbromide staining, using either the $16 \mathrm{~S}$ rDNA primers or the plasmid primers. A weak band indicated partial inhibition of the polymerase.

Altogether 8 kidney or gill samples were PCR amplified simultaneously, including inhibition controls. However duplicate samples from the same fish were not included in the same PCR set up. A negative control sample of $\mathrm{H}_{2} \mathrm{O}$ and a positive control sample of A.s.s. DNA dissolved in $\mathrm{H}_{2} \mathrm{O}$ were included in each PCR set up.

Electrophoretic detection of PCR products. The PCR products $(8 \mu \mathrm{l})$ were loaded on horizontal, $1.0 \%$ agarose gels, and subjected to electrophoresis for $35 \mathrm{~min}$ at $100 \mathrm{~V}$ in Tris-borate buffer (Sambrook et al. 1989). Gels were stained with ethidium bromide, and photographed under UV-light transillumination. A 123 bp DNA ladder (Gibco BRL, Life Technologies Inc., MD, USA) was included as a molecular weight standard on each gel.

Confirmation of PCR products by hybridization. The PCR products were transferred from the agarose gels to nylon membranes (Amersham, UK) by alkali blotting, according to the manufacturer's instructions. Membranes were wrapped in plastic film and stored at $4^{\circ} \mathrm{C}$.

The temperatures throughout the entire hybridization were $62^{\circ} \mathrm{C}$ and $60^{\circ} \mathrm{C}$ for the $16 \mathrm{~S}$ rDNA and plasmid probe, respectively. The membranes were prehybridized for $1 \mathrm{~h}$ in $25 \mathrm{ml}$ of a solution which contained:
$25 \mathrm{ml} 20 \times \mathrm{SSPE}(1 \times \mathrm{SSPE}$ contains $0.18 \mathrm{M} \mathrm{NaCl}$, $0.01 \mathrm{M} \mathrm{NaHPO}_{4}, 1 \mathrm{mM}$ EDTA pH 7.2), $5 \mathrm{ml} 100 \times$ Denhardt's solution $[100 \times$ Denhardt's solution contains $2 \%(\mathrm{w} / \mathrm{v})$ bovine serum albumin, $2 \%(\mathrm{w} / \mathrm{v})$ Ficoll (Pharmacia, Sweden), $2 \%$ (w/v) polyvinylpyrolidone], $5 \mathrm{ml} 10 \%(\mathrm{w} / \mathrm{v})$ sodium dodecyl sulphate (SDS), and $2 \mathrm{ml}$ salmon sperm DNA (1 $\mathrm{mg} \mathrm{ml}^{-1}$ ) denatured at $100^{\circ} \mathrm{C}$ for $5 \mathrm{~min}$, and distilled water ad $100 \mathrm{ml}$. The labeled probe was added, and hybridization was performed for $2 \mathrm{~h}$. The membranes were washed for 10 min with $2 \times$ SSPE - $0.1 \%$ SDS, $1 \times$ SSPE- $0.1 \%$ SDS, and finally with $0.1 \times \mathrm{SSPE}-0.1 \%$ SDS, respectively. The membranes were then autoradiographed overnight at $-70^{\circ} \mathrm{C}$, using intensifying screens (Eastman Kodak Co., NY, USA).

A.s.s. was considered detected by PCR in kidney tissue or gill swabs when spots were demonstrated on the intensifying screens after hybridization which corresponded to the molecular size of the PCR product of the positive control sample.

Determination of $\mathrm{PCR}$ in vitro sensitivity. A.s.S. ATCC 14174 and a Norwegian isolate of A.s.s. (7058/91) from a clinical outbreak of furunculosis were incubated at $22^{\circ} \mathrm{C}$ for $24 \mathrm{~h}$ in brain heart infusion broth (BHI) (Difco). The number of colony forming units (CFU) was determined by 10 -fold dilution in saline and drop plating on BA plates, followed by incubation at $22^{\circ} \mathrm{C}$ for $48 \mathrm{~h}$ (Hoben \& Somasegaran 1982). Various numbers of CFU in $100 \mu$ l aliquots from the 10 -fold dilutions were added to $100 \mu \mathrm{l}$ kidney tissue suspensions and gill swabs soaked in $1 \mathrm{ml}$ PBS, and prepared for PCR as previously described. The organ samples were collected from fish considered not infected with $A$.s.s.

Determination of PCR in vitro specificity. The bacterial species used are listed in Table 2 . The bacteria were grown aerobically at $15^{\circ} \mathrm{C}$ or $22^{\circ} \mathrm{C}$ in $5 \mathrm{ml} \mathrm{BHI}$ with or without $2 \% \mathrm{NaCl}$, depending upon $\mathrm{NaCl}$ requirements for growth, from stock cultures kept frozen at $-70^{\circ} \mathrm{C}$. A total of $1 \mathrm{ml}$ bacterial culture was centrifuged at $12000 \times g$ for $2 \mathrm{~min}$. The pellet was 
Table 2. Bacterial strains used for the determination of the in vitro specificity of the primers and probes

\begin{tabular}{|c|c|c|c|c|c|}
\hline \multirow[t]{2}{*}{ Bacterial strain } & \multirow[t]{2}{*}{ Source of isolate } & \multicolumn{2}{|c|}{$16 \mathrm{~S} \mathrm{rDNA}$} & \multicolumn{2}{|c|}{ Plasmid } \\
\hline & & Ethidium bromide & Hybridization & Ethidium bromide & Hybridization \\
\hline Actinobacillus lignieresii & ATCC $19393^{\mathrm{d}}$ & - & - & - & - \\
\hline Aeromonas caviae & NCIMB $13016^{b}$ & - & - & - & - \\
\hline Aeromonas eucrenophila & NCIMB 74 & - & - & - & - \\
\hline Aeromonas hydrophila & ATCC 14715 & + & + & - & - \\
\hline Aeromonas media & NCIMB 2237 & - & - & - & - \\
\hline A. salmonicida ss achromogenes & NCIMB 1110 & + & + & + & + \\
\hline A. salmonicida ss masoucida & ATCC 27013 & + & + & - & - \\
\hline A. salmonicida ss salmonicida & ATCC 14174 & + & + & + & + \\
\hline A. salmonicida ss salmonicida & 7058/91-Norway & + & + & + & + \\
\hline Aeromonas sobria & NCIMB 12065 & - & - & - & - \\
\hline Aeromonas veronii & NCIMB 13015 & - & - & - & - \\
\hline Atypical Aeromonas salmonicida & 2779/89-Norway & + & + & - & - \\
\hline Atypical Aeromonas salmonicida & 4251/89-Norway & + & + & - & - \\
\hline Escherichia coli & ATCC 11303 & - & - & - & - \\
\hline Pasteurella piscicida & NCIMB 2058 & - & - & - & - \\
\hline Photobacterium phosphoreum & NCIMB 1282 & - & - & - & - \\
\hline Plesiomonas shigelloides & ATCC 14029 & - & - & - & - \\
\hline Vibrio anguillarum O-1 & ATCC 43305 & - & - & - & - \\
\hline Vibrio anguillarum $\mathrm{O}-2$ & ATCC 14181 & - & - & - & - \\
\hline Vibrio logei & ATCC 29935 & - & - & - & - \\
\hline Vibrio marinus & NCIMB 1144 & - & - & - & - \\
\hline Vibrio orientalis & NCIMB 2195 & - & - & - & - \\
\hline Vibrio pelagius I & NCIMB 1900 & - & - & - & - \\
\hline Vibrio pelagius II & NCIMB 2253 & - & - & - & - \\
\hline Vibrio salmonicida & ATCC 43839 & - & - & - & - \\
\hline Vibrio splendidus I & NCIMB 1 & - & - & - & - \\
\hline Vibrio splendidus II & NCIMB 2251 & - & - & - & - \\
\hline Vibrio vulnificus & $\operatorname{ATCC} 33147$ & - & - & - . & - \\
\hline Yersinia ruckeri & ATCC 29473 & - & - & - & - \\
\hline
\end{tabular}

resuspended in $100 \mu \mathrm{l}$ PCR buffer and processed in the same way as the gill samples.

Experimentally infected Atlantic salmon parr. Parr, average weight $50 \mathrm{~g}$, were challenged by cohabitation with parr injected intraperitoneally with A.s.s. The experiment was performed at VESO Akvavet Research Station, Namsos, Norway. After 2 wk kidney samples were obtained from 5 moribund cohabitants. Another 20, apparently healthy cohabitants were sampled at the end of the experiment, 1 mo after challenge, when the surviving fish were stunned by a blow to the head.

Atlantic salmon at slaughter. Mid kidney samples and gill swabs, 2 from each fish, were collected at slaughter in March 1991 from farmed Atlantic salmon weighing about $2 \mathrm{~kg}$. The fish had not been vaccinated against furunculosis.

Altogether 53 fish from a farm that had experienced an outbreak of furunculosis 6 mo prior to slaughter were sampled. A.s.s. had been isolated from diseased fish during the outbreak and the fish had been treated by the incorporation of oxolinic acid in the feed. These fish were considered to be covertly infected with A.s.s.
Additionally, 56 fish originating from a farm located in a fjord with no previous history of furunculosis were also sampled. These fish were considered not to be infected with A.s.s.

Feral brood fish. Mid kidney samples from feral brood fish of Atlantic salmon from 5 different river systems were collected at spawning (Table 3). River no. 1

Table 3. Numbers of fish sampled from each river and numbers of positive fish demonstrated, i.e. A.s.s. detected by agar cultivation or by $\mathrm{PCR}$, using $16 \mathrm{~S}$ rDNA and plasmid primers, and probes

\begin{tabular}{lcccc|}
\hline $\begin{array}{l}\text { River } \\
\text { no. }\end{array}$ & $\begin{array}{c}\text { No. of } \\
\text { fish }\end{array}$ & $\begin{array}{c}\text { Culture } \\
\text { positive }\end{array}$ & $\begin{array}{c}\text { 16S rDNA } \\
\text { positive }\end{array}$ & $\begin{array}{c}\text { Plasmid } \\
\text { positive }\end{array}$ \\
\hline 1 & 16 & 0 & 5 & 0 \\
2 & 6 & 2 & 3 & 0 \\
3 & 2 & 2 & 2 & 0 \\
4 & 25 & 2 & 8 & 0 \\
5 & 39 & 0 & 11 & 0 \\
Totals & 88 & 6 & 29 & 0 \\
\hline
\end{tabular}


had no previous history of furunculosis. Broodfish used for restocking purposes had been clinically and bacteriologically examined over many years, and the commercial fish farms of the county had never experienced outbreaks of furunculosis. Rivers nos. 2 to 5 had previous histories of furunculosis as verified by isolation of A.s.s.

\section{RESULTS}

\section{$\mathrm{PCR}$ in vitro sensitivity}

Using the $16 \mathrm{~S}$ rDNA primers and probe, the detection limit was $20 \mathrm{CFU}$ in the $10 \mu \mathrm{PCR}$ templates from kidney and gill preparations, while the corresponding figure for the plasmid primers and probe was $200 \mathrm{CFU}$. From this it follows that $10^{3}$ and $10^{4}$ CFU were detectable in $100 \mu$ l kidney suspensions and gill swabs, using the $16 \mathrm{~S}$ rDNA and plasmid primers, respectively.

\section{PCR in vitro specificity}

The results of the specificity testing are summarized in Table 2. Using the $16 \mathrm{~S}$ IDNA primers, bands the size of which were consistent with a $271 \mathrm{bp}$ fragment were visualized for A.s.s., A. hydrophila, A. salmonicida ss achromogenes, $A$. salmonicida ss masoucida, and the atypical $A$. salmonicida isolates. These PCR products hybridized with the $16 \mathrm{~S}$ rDNA probe (Fig. 1).

Using the plasmid primers, PCR products of expected size which hybridized with the plasmid probe were demonstrated for A.s.s. and A. salmonicida ss achromogenes.

\section{Experimentally infected Atlantic salmon parr}

A.s.s. was demonstrated by agar cultivation and PCR with $16 \mathrm{~S}$ rDNA primers and probe in the 5 moribund fish which were sampled after 2 wk. Additionally, A.s.s. was detected by PCR in 7 apparently healthy fish. Discordance between duplicate samples from 4 of these 7 fish was demonstrated. A.s.s. was demonstrated by cultivation in 1 out of these 7 . The results of the examinations are presented in Table 4 and Fig. 2. A.s.s. was not detected by PCR using the plasmid primers and probe.

\section{Atlantic salmon at slaughter: kidney samples}

A.s.s. was not detected by agar cultivation or PCR in any of the kidney samples.

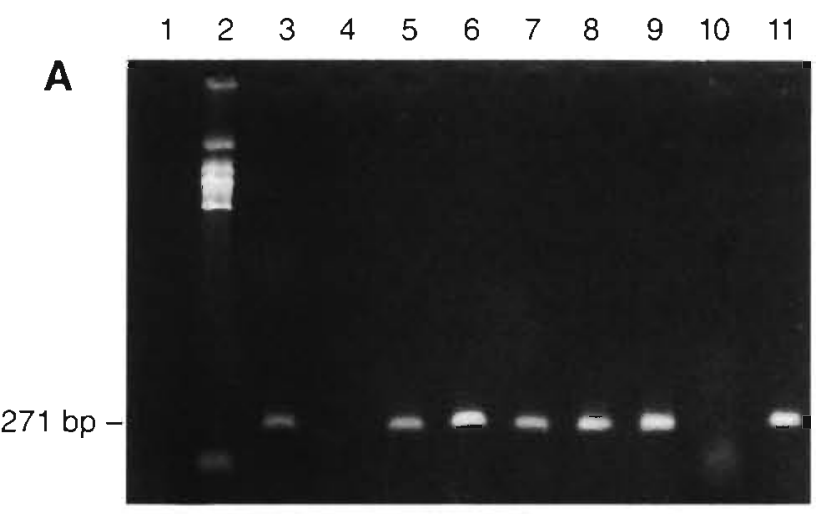

B

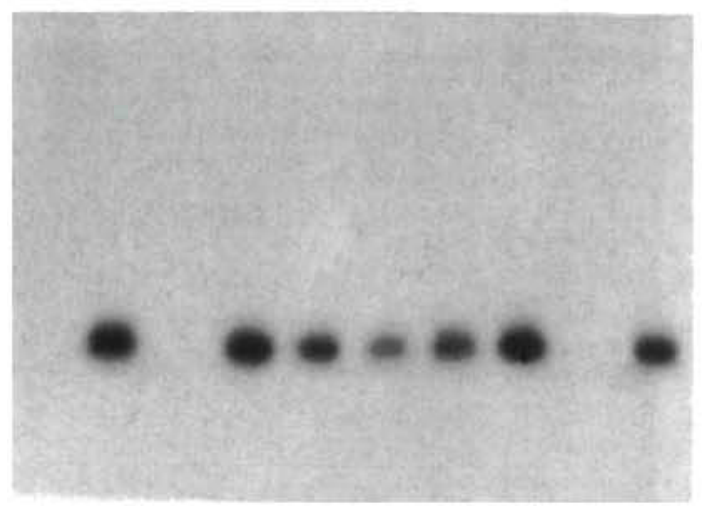

Fig. 1. Specificity testing of (A) the $16 \mathrm{~S}$ rDNA primers and (B) the $\left[\gamma^{32}\right.$ P]ATP labeled $16 \mathrm{~S}$ rDNA probe by using DNA from Aeromonas salmonicida ss achromogenes (lane 3 ), A. eucrenophila (lane 4), A. hydrophila (lane 5), A. salmonicida ss masoucida (lane 6), A.s.s. (lane 7), atypical A. salmonicida (lane 8), atypical A. salmonicida (lane 9), and P. piscicida (lane 10). A negative control $\left(\mathrm{H}_{2} \mathrm{O}\right)$ is shown in lane 1 , and lane 11 is a positive control (A.s.s. DNA in $\mathrm{H}_{2} \mathrm{O}$ ). Lane 2 is the DNA ladder

Employing the 16 S rDNA primers, amplification products whose size was consistent with a 271 bp fragment, but which did not hybridize with the $16 \mathrm{~S}$ rDNA probe, were demonstrated in kidney samples from fish considered infected with A.s.S., as well as in samples from fish considered not infected (Fig. 3, Table 5A). Discordance between duplicate samples was ob-

Table 4. Distribution of 20 kidney samples from apparently healthy parr, experimentally infected with A.s.s. by cohabitation, with respect to the detection of A.s.s. using agar cultivation and OCR with $16 \mathrm{~S}$ rDNA primers and radioactively labeled 16S rDNA probe

\begin{tabular}{|lccc|}
\hline \multirow{2}{*}{$\begin{array}{l}\text { Kidney } \\
\text { samples }\end{array}$} & Cultivation & \multicolumn{2}{c|}{ PCR (16S rDNA) } \\
& & Duplicate 1 & Duplicate 2 \\
\hline Positive & 1 & 5 & 7 \\
Negative & 19 & 15 & 13 \\
Totals & 20 & 20 & 20 \\
\hline
\end{tabular}




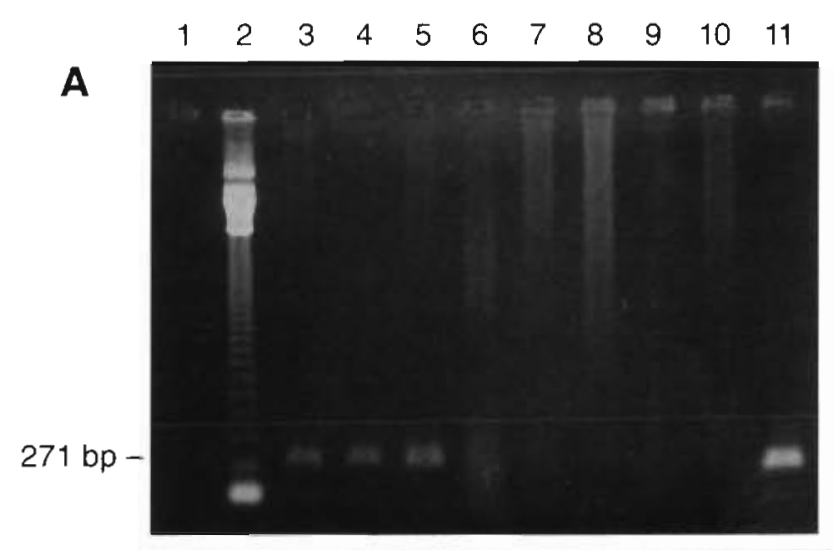

B

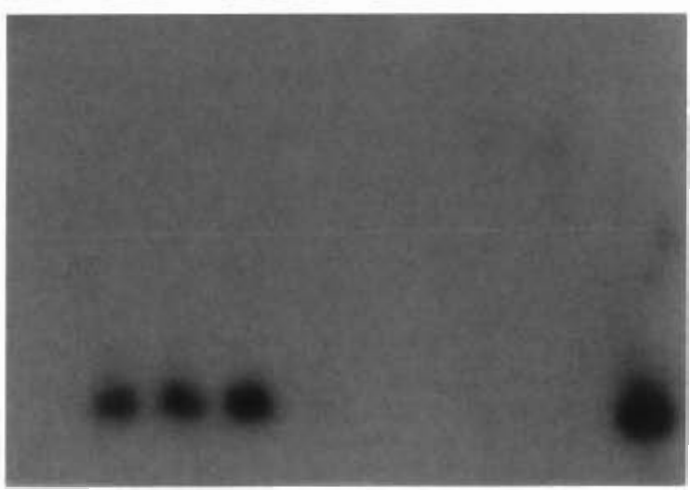

Fig. 2. Salmo salar. PCR testing of experimentally challenged parr using the 16S rDNA primers (lanes 3 to 10). (A) Products of expected size (271 bp), visualized by ethidium bromide, were demonstrated (lanes 3 to 5). (B) The $271 \mathrm{bp}$ amplified products were confirmed by the $\left[\gamma^{-32}\right.$ P]ATP labeled $16 \mathrm{~S}$ rDNA. probe. A negative control $\left(\mathrm{H}_{2} \mathrm{O}\right)$ is shown in lane 1 , and lane 11 is a positive control (A.s.s. DNA in $\mathrm{H}_{2} \mathrm{O}$ ). Lane 2 is the DNA ladder

served; PCR products of expected size, visualized by ethidium bromide, were detected in both duplicates of only 6 kidney samples.

Employing the plasmid primers, PCR products of expected size, visualized by ethidium bromide, were not detected in any of the samples considered infected with A.s.s. (Table 5B). In kidney samples from fish considered not infected, PCR products which did not hybridize with the plasmid probe were demonstrated in 17 samples, but only in one of the duplicates.

Total inhibition of the PCR was not demonstrated in any of the kidney samples. Partial inhibition was demonstrated in only 5 out of $2 \times 109$ duplicate samples.

\section{Atlantic salmon at slaughter: gill swabs}

A.s.s. was not detected by agar cultivation or PCR in any of the gill swabs.

No PCR products of expected size, visualized by ethidium bromide, were demonstrated in any of the gill

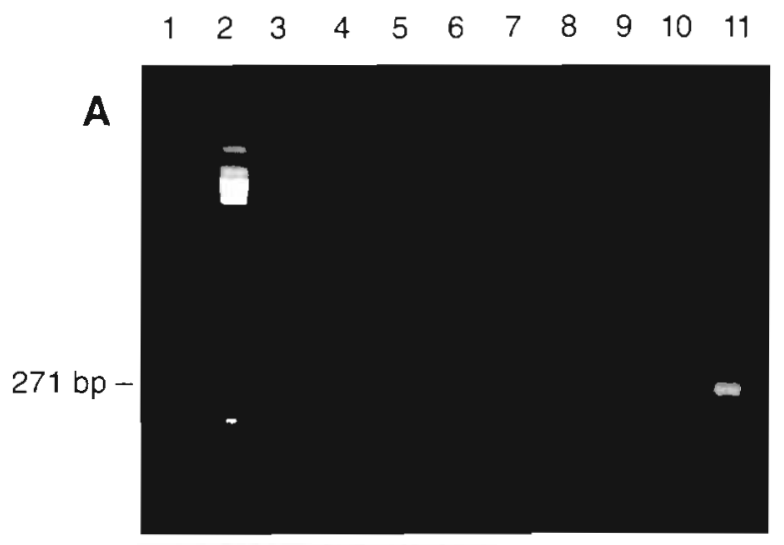

B

Fig. 3. Salmo salar. PCR testing of kidneys of fish considered infected with Aeromonas salmonicida ss salmonicida at slaughter using the 16S rDNA primers (lanes 3 to 10). (A) Products of expected size ( $271 \mathrm{bp})$, visualized by ethidium bromide, were demonstrated in kidneys (lanes 4 to 9). (B) However, the $271 \mathrm{bp}$ amplified products were not confirmed by the $\left[\gamma^{32}\right.$ P $]$ ATP labeled $16 \mathrm{~S}$ rDNA probe. A negative control $\left(\mathrm{H}_{2} \mathrm{O}\right)$ is shown in lane 1 , and lane 11 is a positive control (A.s.s. DNA in $\mathrm{H}_{2} \mathrm{O}$ ). Lane 2 is the DNA ladder

swabs, employing the $16 \mathrm{~S}$ rDNA or plasmid primers (Fig. 4).

Total inhibition of the PCR was demonstrated in 16 duplicate samples from gills, while partial inhibition was demonstrated in 10 (Fig. 4).

Table 5. Distribution of 53 kidney samples from fish considered covertly infected with A.s.s., and 56 kidney samples from fish never exposed to A.s.s. in relation to $(A)$ the $271 \mathrm{bp} \mathrm{PCR}$ products amplified by the $16 \mathrm{~S}$ rDNA primers and stained by ethidium bromide, (B) the ca $710 \mathrm{bp}$ PRC products amplified by the plasmid primers and stained by ethidium bromide

\begin{tabular}{|c|c|c|c|c|}
\hline $\begin{array}{l}\text { Kidney } \\
\text { samples }\end{array}$ & $\begin{array}{l}\text { Dupl } \\
\text { Positive }\end{array}$ & $\begin{array}{l}\text { licate } 1 \\
\text { Negative }\end{array}$ & $\begin{array}{l}\text { Duplid } \\
\text { Positive }\end{array}$ & $\begin{array}{l}\text { cate } 2 \\
\text { Negative }\end{array}$ \\
\hline \multicolumn{5}{|c|}{ A. PCR products: $16 \mathrm{~S}$ rDNA primers } \\
\hline Infected & 10 & 43 & 16 & 37 \\
\hline Not infected & 21 & 35 & 12 & 44 \\
\hline Totals & 31 & 78 & 28 & 81 \\
\hline \multicolumn{5}{|c|}{ B. PCR products: plasmid primers } \\
\hline Infected & 0 & 53 & 0 & 53 \\
\hline Not infected & 17 & 39 & 0 & 56 \\
\hline Totals & 17 & 92 & 0 & 109 \\
\hline
\end{tabular}


Fig. 4. Salmo salar. PCR testing of gill swabs of fish considered not infected with Aeromonas salmonicida ss salmonicida at slaughter using the plasmid primers (lanes 3 to 10). (A) No products of expected size (710 bp) were demonstrated by ethidium bromide staining and the $\left[\gamma^{32} \mathrm{P}\right]$ labeled plasmid probe. (B) Inhibition controls of gill swabs exhibited varying degree of partial inhibition of the polymerase (lanes 3, 5, 6, 8 , and maybe 10). Total inhibition was present in lane 4. A negative control $\left(\mathrm{H}_{2} \mathrm{O}\right)$ is shown in lane 1 , and lane 11 is a positive control (A.s.s. DNA in $\mathrm{H}_{2} \mathrm{O}$ ). Lane 2 is the DNA ladder

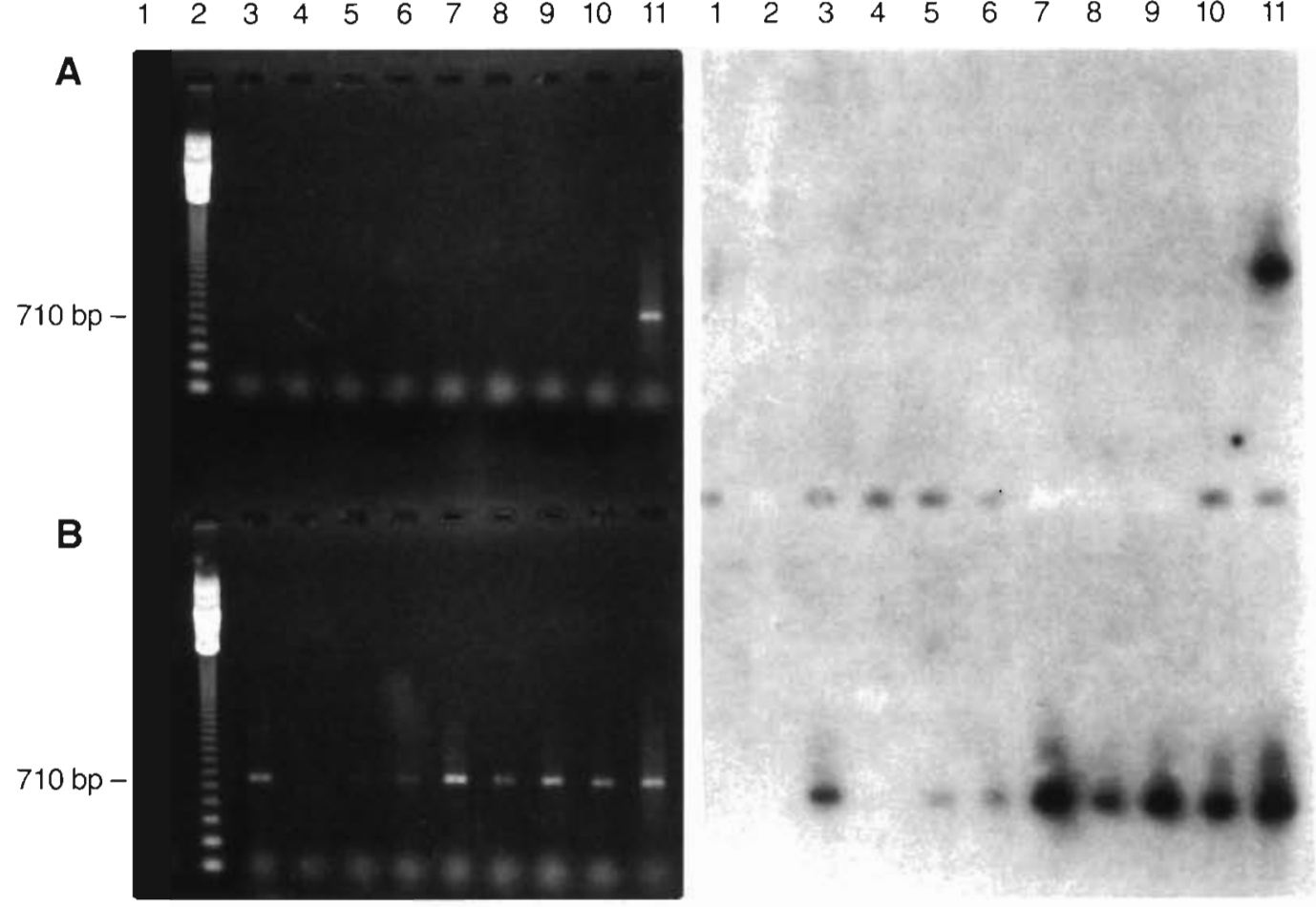

\section{Feral brood fish}

The results of cultivation and PCR testing of the kidney samples are shown in Table 3. A.s.s. was more frequently detected by PCR (24/72) compared with cultivation $(6 / 72)$ when the $16 \mathrm{~S}$ rDNA primers and probe were employed. However, A.s.s. was also demonstrated by PCR in fish from River no. $1(5 / 16)$ which had no previous history of furunculosis or isolation of the bacterium.

A.s.s. was not detected by PCR using the plasmid primers and probe.

\section{DISCUSSION}

A.s.s. was demonstrated by PCR using $16 \mathrm{~S}$ rDNA primers and probe in a higher proportion (13/25) of the samples from experimentally challenged parr, compared to agar cultivation (6/25). Similar findings were made in feral brood fish from rivers with a history of furunculosis, as 24/72 were positive with PCR and 6/72 by agar cultivation. Thus, the sensitivity of the PCR assay is higher than agar cultivation. However, the fish sampled at slaughter were negative by PCR and cultivation, indicating that the methods are not sensitive enough to detect infection under such conditions.

Others have also successfully detected A.s.s. by PCR in fish (Gustafson et al. 1992). Primers of sequences derived from the surface array protein gene were employed. The fish tested were small, apparently healthy trout, which had either been exposed to A.s.s. by intraperitoneal injection of a sublethal dose or had been held in a tank with fish that had died of furunculosis. No agar cultivation was performed for comparison. Kidney, spleen and faeces from the trout were prepared for PCR both before and after $24 \mathrm{~h}$ incubation in broth. Altogether 20/25 fish tested positive by PCR without broth incubation, while $25 / 25$ tested positive after broth incubation. In order to determine the in vitro sensitivity, serial dilutions of A.s.s. were added to kidney, spleen and feces from a rainbow trout $O n c o-$ rhynchus mykiss which was known never to have been exposed to A.s.s. The detection level of the PCR assay

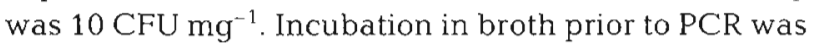
not performed. In the present study the detection level of the PCR assay was $10^{3}$ CFU per $100 \mu$ l kidney tissue suspension, using the $16 \mathrm{~S}$ rDNA primers and probe. This is comparable with the $10 \mathrm{CFU} \mathrm{\textrm {mg } ^ { - 1 }}$ fish tissue mentioned above. The difference between the studies in the rates of recovery of A.s.S. in experimentally infected fish indicates different sensitivities of the PCR assays. However, as the experimental conditions seem significantly different between the studies, a comparison of the recovery rates might not be valid.

The in vitro sensitivity trials and the testing of experimentally challenged fish and feral brood fish revealed that PCR with $16 \mathrm{~S}$ rDNA primers as well as agar culti- 
vation were more sensitive than PCR with plasmid primers. This may be due to the relatively high annealing temperature used for the plasmid primers. The 4fold difference in primer concentration between the primer sets may also be of significance when PCR is employed on tissue in which high concentrations of eucaryote DNA are present.

In the PCR in vitro specificity testing, DNA from bacteria other than A.s.s. was amplified by the plasmid as well as the 16S rDNA primer set. These PCR products hybridized with the corresponding probes. The plasmid primers were more specific than the $16 \mathrm{~S}$ rDNA primers. It has been found that the base sequences of 16S rRNA of various Aeromonas spp. differ very little (Martinez-Murcia et al. 1992). The 271 bp sequence of 16S rRNA used in the present study was identical for A.s.s., A. salmonicida ss achromogenes, and A. salmonicida ss masoucida. Primers derived from other base sequences of $A$. salmonicida have also been investigated (Gustafson et al. 1992, Hiney et al. 1992), but these primers did not distinguish between typical and atypical A. salmonicida, which emphasises the difficulties in finding primers and probes specific for A.s.S.

Employed on fish samples, the specificity of the PCR assay seems to vary with the origin of the fish. A.s.s. was demonstrated by PCR, using $16 \mathrm{~S}$ rDNA primers and probe, in 5/16 feral brood fish from a riversystem with no history of furunculosis. These are 'false positives'. No 'false positives' were demonstrated among fish sampled at slaughter. In a previous study by Høie et al. (1996), altogether 10 parr not challenged with A.s.s., from VESO Akvavet Research Station, tested negative by the PCR assay employed here, indicating high specificity. These findings indicate that despite a questionable in vitro specificity, the specificity of the assay employed on field samples can still be acceptable, but it can vary with the kind of field samples used for testing. Agar cultivation methods for the detection of A.s.s. have low sensitivity, but their specificity is high, close to $100 \%$ in laboratories with experience in bacterial examinations for A.s.s.

A.s.s. was not demonstrated in fish sampled at slaughter. It was assumed that the fish were infected 6 mo after the outbreak of furunculosis and treatment with oxolinic acid. It is still a matter of discussion whether or not antibiotic treatment completely removes the bacterium from the fish tissue. But it has been shown that fish shed bacteria during a furunculosis outbreak (Rose et al. 1990) and the bacterium can survive in the environment, probably for months (Austin \& Austin 1993). So, reinfection will probably occur.

PCR products of expected size were demonstrated in fish sampled at slaughter, but these amplification prod- ucts did not hybridize with the probes. Agar cultivation demonstrated small numbers of bacteria other than A.s.s. in the majority of gill and kidney samples. These bacteria were not characterized. Various environmental bacteria are present on gills, and it is almost impossible to avoid contamination of kidney samples with process water during collection of tissues at a commercial slaughter facility. The amplified DNA that was demonstrated points to the possible existence of environmental bacteria, other than those tested during the in vitro specificity trials, which are genetically related to A.s.s.

Discordant results between duplicate samples from experimentally challenged fish were experienced. This difference between duplicates indicates that the bacteria are not equally distributed in samples obtained from the same organ of a fish. However, it may also reflect problems associated with reproducibility of PCR when used for the detection of infectious agents in clinical specimens. Sensitivity controls were not used in the present study, but, as part of a system for the control of reproducibility, such controls should probably be included. Others have concluded that an effective system for monitoring sensitivity and specificity is required before the PCR can be used reliably in the diagnosis of tuberculosis (Noordhoek et al. 1994).

Discordance was also revealed in the PCR testing of slaughter fish samples, as the detection of amplification products which did not hybridize with the probes varied between duplicates. One explanation for this might be that there are differences of the bacterial flora between duplicates.

In the present study, an intracellular localization of A.s.S. in the kidney tissue was assumed, and Proteinase $\mathrm{K}$ and sonication were used to break down the cell membranes. Non-target, eucaryote DNA will therefore be present at amplification. It has been shown that non-target DNA above a certain concentration inhibits PCR (Picard et al. 1992), and could therefore inhibit the amplification of A.s.s. DNA in kidney samples. It has also been indicated that fish cells in numbers above $10^{6}$, when processed as the kidney suspensions in the present study, will inhibit the amplification (Høie et al. 1996). In order to keep the concentration of eucaryote DNA below a critical limit, the standardization of the amount of kidney tissue to be prepared becomes essential. Partial inhibition was experienced in a few kidney samples, indicating that the concentration of DNA was close to a maximum. Amplification was also inhibited in gill samples. However, other reasons for inhibition are more likely in these samples, as only small numbers of tissue cells will be present.

In conclusion, the results suggest that the sensitivity as well as the specificity of the PCR method are not 
high enough to recommend the method for detection of covertly infected fish under field conditions. However, there are difficulties defining proper field material for validation, as covert A.s.s. infection is still relatively poorly understood. Mid kidney samples were used because mid kidney is the preferred organ for bacterial investigations of diseases in fish. However, mid kidney might not be the optimal organ for demonstration of covert infections. Furthermore, a PCR test represents very small amounts of tissue. Therefore, the tissue sample that is tested might not be representative of the covertly infected fish.

Acknowledgements. This work was supported by the Norwegian Research Council. We thank Dr H. Sørum, Norwegian College of Veterinary Medicine, for the provision of sequences of the $5.0 \mathrm{~kb}$ plasmid of A.s.s.

\section{LITERATURE CITED}

Adams A, Thompson K (1990) Development of an enzymelinked immunosorbent assay (ELISA) for the detection of Aeromonas salmonicida in fish tissue. $J$ Aquat Anim Health 2:281-288

Austin B, Austin DA (1993) Bacterial fish pathogens: disease in farmed and wild fish, 2nd edn. Ellis Horwood Ltd, Chichester

Austin DA, McIntosh D, Austin B (1989) Taxonomy of fish associated Aeromonas spp., with the description of Aeromonas salmonicida subsp. smithia subsp. nov. J Syst Appl Microbiol 11:277-290

Belland RJ, Trust TJ (1988) DNA:DNA reassociation analysis of Aeromonas salmonicida. J Gen Microbiol 134:307-315

Boyd EF, Hiney MP, Peden JF, Smith PR (1994) Assessment of genetic diversity among Aeromonas salmonicida isolates by multilocus enzyme electrophoresis. J Fish Dis 17:97-98

Bullock GL, Stuckey HM (1975) Aeromonas salmonicida: detection of asymptomatically infected trout. Prog FishCult 37:237-239

Gustafson CE, Thomas CJ, Trust TJ (1992) Detection of Aeromonas salmonicida by using polymerase chain reaction amplification of the virulence surface array protein gene. Appl Environ Microbiol 58:3816-3825

Higuchi R (1989) Simple and rapid preparation of samples for PCR. In: Erlich A (ed) PCR technology. Principles and applications for DNA amplification. Stockton Press, New York, $\mathrm{p} 31-38$

Hiney MP, Dawson MT, Heery DM, Smith PR, Gannon F, Powell R (1992) DNA probe for Aeromonas salmonicida. Appl Environ Microbiol 58:1039-1042

Hiney MP, Kilmartin JJ, Smith PR (1994) Detection of Aeromonas salmonicida in Atlantic salmon with asymptomatic

Responsible Subject Editor: L. Vaughan, Dublin, Ireland furunculosis infections. Dis Aquat Org 19:161-167

Hoben HJ, Somasegaran P (1982) Comparison of the pour, spread, and drop plate methods for enumeration of Rhizobium spp. in inoculants made from presterilized peat. Appl Environ Microbiol 44:1246-1247

Hoie S, Heum M, Thoresen OF (1996) Detection of Aeromonas salmonicida by polymerase chain reaction in Atlantic salmon vaccinated against furunculosis. Fish Shellfish Immunol 6:199-206

Inglis V, Roberts RJ, Bromage NR (1993) Bacterial diseases of fish. Blackwell Scientific Publications, Oxford

Martinez-Murcia AJ, Benlloch S, Collins MD (1992) Phylogenetic interrelationships of members of the genera Aeromonas and Plesiomonas as determined by $16 \mathrm{~S}$ Ribosomal DNA Sequencing: lack of congruence with results of DNA-DNA hybridizations. Int J Syst Bact 42:412-421

McCarthy DH, Roberts RJ (1980) Furunculosis of fish - the present stage of our knowledge. Adv Aquat Microbiol 2: $293-340$

Noordhoek GT, Kolk AHJ, Bjune G, Catty D, Dale JW, Fine PEM, Godfrey-Faussett P, Sang-Nae C, Shinnick T, Svenson SB, Wilson S, van Emden JDA (1994) Sensitivity and specificity of PCR for detection of Mycobacterium tuberculosis: a blind comparison study among seven laboratories. J Clin Microbiol 32:277-284

O'Brian D, Mooney J, Ryen D, Powell E. Hiney M, Smith PR, Powell R (1994) Detection of Aeromonas salmonicida, causal agent of furunculosis in salmonid fish, from the tank effluent of hatchery-reared Atlantic salmon smolts. Appl Environ Microbiol 60:3874-3877

Picard C, Ponsonnet C, Paget E, Nesme X, Simonet P (1992) Detection and enumeration of bacteria in soil by direct DNA extraction and polymerase chain reaction. Appl Environ Microbiol 58:2717-2722

Popoff M (1984) Genus IIl. Aeromonas Kluyver and van Niel 1936. In: Krieg NR, Holt JG (ed) Bergey's manual of systematic bacteriology, Vol 1. The Williams \& Wilkins Co, Baltimore, p 545-548

Rose AS, Ellis AE, Adams A (1989) An assessment of routine Aeromonas salmonicida carrier detection by ELISA. Bull Eur Assoc Fish Pathol 9:65-67

Rose AS, Ellis AE, Munro ALS (1990) The infectivity by different routes of exposure and shedding rates of Aeromonas salmonicida subsp. salmonicida in Atlantic salmon, Salmo salar L., held in sea water. J Fish Dis 12:573-578

Saiki R, Gelfand S, Stoffel S, Higuchi R, Mullis K, Ehrlich H (1988) Primer-directed enzymatic amplification of DNA with a thermostable DNA polymerase. Science 239 $487-491$

Sambrook J, Fritsch EF, Maniatis TJ (1989) Molecular cloning: a laboratory manual, 2nd edn. Cold Spring Harbor Laboratory Press, New York

Sørum H, Kvello JH, Håstein T (1993) Occurrence and stability of plasmids in Aeromonas salmonicida ss salmonicida isolated from salmonids with furunculosis. Dis Aquat Org 16:199-206

Manuscript received: December 2, 1996

Revised version accepted: April 25, 1997 